
\title{
28 Research Square \\ Product Comparison for Slow and Fast Pyrolysis of Flax Shive
}

\section{Yury V. Lugovoy}

Tverskoj gosudarstvennyj tehniceskij universitet

Kirill V. Chalov

Tverskoj gosudarstvennyj tehniceskij universitet

Antonina Stepacheva ( $\nabla$ a.a.stepacheva@mail.ru )

Tverskoj gosudarstvennyj tehniceskij universitet https://orcid.org/0000-0001-9366-5201

Yury Yu. Kositsov

Tverskoj gosudarstvennyj tehniceskij universitet

Mikhail G. Sulman

Tverskoj gosudarstvennyj tehniceskij universitet

\section{Research Article}

Keywords: flax shive, agricultural waste, fast pyrolysis, slow pyrolysis, product composition

Posted Date: January 27th, 2022

DOI: https://doi.org/10.21203/rs.3.rs-1275952/v1

License: (c) (i) This work is licensed under a Creative Commons Attribution 4.0 International License. Read Full License 


\section{Abstract}

In the current work, a comparison of the composition and properties of products obtained by the slow and fast pyrolysis of flax shive is presented to evaluate the influence of the process mode on the thermal decomposition of agricultural waste. The thermogravimetric studies were carried out to estimate the temperature range of the decomposition of the feedstock main component (cellulose, hemicelluloses, and lignin) and to choose the pyrolysis temperature. It was found that the slow pyrolysis was found to provide the higher conversion depth of the feedstock resulting in the formation of gaseous and liquid products with higher calorific values $\left(9.65 \mathrm{MJ} / \mathrm{m}^{3}\right.$, and $16.51 \mathrm{MJ} / \mathrm{kg}$ respectively). Moreover, the solid residue of the slow pyrolysis was characterized by the higher surface area and narrow pore size distribution in comparison with that obtained by the fast process.

\section{Introduction}

Environmental problems related to the use of fossil fuels as well as the diminishing of oil reserves result in the focus on alternative energy sources. As one of such alternatives, biomass is considered to be a carbon-neutral, eco-friendly, renewable, and low-cost feedstock for the production of fuels and chemicals. There are a lot of studies on biomass processing including thermal, electrochemical, and biochemical methods. However, thermal conversion remains the major approach for the conversion of this renewable source $[1,2]$. Among thermal methods, pyrolysis is one of the most suitable for the production of valueadded products (i.e. combustible gas, bio-oil, and bio-char) [3-7].

The pyrolysis product yield and composition strongly depend on the process conditions, catalyst presence, reactor type, feedstock pretreatment, and the heating mode [8-10]. Two main technologies can be applied for the successful conversion of biomass to valuable compounds. The first one is the slow pyrolysis which consists of the slow heating $\left(5-10^{\circ} \mathrm{C} / \mathrm{min}\right)$ of feedstock with a high retention time in the heating zone. The second one is fast pyrolysis which includes fast heating $\left(100-120^{\circ} \mathrm{C} / \mathrm{min}\right)$ of biomass [11-13]. According to the literature data, slow pyrolysis mainly results in the formation of noncondensable gases and char $[14,15]$, while the fast one allows a high yield of bio-oil to be produced $[6$, 16].

The comparison of the products for fast and slow pyrolysis of biomass was presented in numerous studies [6, 17-20]. Here we report the results of the studies of thermal decomposition of the agricultural wastes by these two approaches. This work is focused on the yield, composition, and properties of gaseous, liquid, and solid products obtained by slow and fast pyrolysis of the secondary product of flax processing - flax shive. The composition and properties of this waste are close to wood pulp. Besides, flax shive is a low-cost and prospective material that can be used for energy production.

\section{Experimental}

\subsection{Initial Feedstock}


Flax shive collected from the Torzhok district of Tver region was purchased from the Federal Research Center of Bast-Fiber Crop and used as received. The characteristics of the initial feedstock were estimated according to the standard procedures. The total humidity of the flax shive was determined by the thermogravimetric method described in [21]. Ash content in the flax shive was determined according to the procedure described in [22]. The lower calorific value of the flax shive was determined using the bomb adiabatic calorimeter ABK-1 (Retech, Russia) according to [23]. Studies of the flax shive composition were performed according to the methods described in [24].

According to the experiments, the following feedstock properties and composition were obtained (see Table 1).

Table 1

Composition and characteristics of flax shive used for pyrolysis

\begin{tabular}{|ll|}
\hline Characteristics & Value \\
\hline Component composition, \% (wt.) & 15.2 \\
Hemicelluloses & 38.1 \\
Cellulose & 27.7 \\
Lignin & 9.9 \\
Extractives & \\
\hline Elemental composition, \% (wt.) & 46.9 \\
C & 5.7 \\
H & 0.6 \\
N Thermogravimetric analysis & 37.5 \\
& O \\
\hline S & 0.1 \\
\hline Humidity, \% (wt.) & 3.8 \\
\hline Ash content, \% (wt.) & 4.2 \\
\hline Lower calorific value, MJ/kg & 17.3 \\
\hline
\end{tabular}

To estimate the thermal stability of the flax shive and choose the temperature range for pyrolysis, the thermogravimetric analysis was performed using TG 209 F1 NETZSCH (Netzch Group, Germany). The sample heating was carried out at the constant heating rate $\left(10^{\circ} \mathrm{C} / \mathrm{min}\right)$ in the inert atmosphere (argon, $99.9 \%$, AGA, Russia). The temperature range of $50-600^{\circ} \mathrm{C}$ was chosen for the analysis. Flax shive samples were preliminary milled and the fraction with the particle size below $0.25 \mathrm{~mm}$ was taken. The 
mathematical modeling of the thermograms was performed using NETZSCH Thermokinetics 3.1 (Netzch Group, Germany).

\subsection{Slow pyrolysis procedure}

The slow pyrolysis of flax shive was carried out in a batch reactor included in the experimental setup presented in Figure 1.

A sample of the flax shive with the weight of $3 \mathrm{~g}$ was loaded into the reactor (1) and purged with nitrogen using a valve (2). The reactor was heated up to the experimental temperature using an electric furnace (6) equipped with the heat controller (7) with a patch thermocouple. The experimental setup is equipped with a sampler (3) for gas sampling and water trap (4) for the separation of liquid pyrolysis products. The weights of solid and liquid products were determined as the difference between the mass of the reactor and liquid trap before and after the experiment. The gaseous products are collected in a eudiometer (5). The slow pyrolysis of flax shive was performed at a temperature of $600^{\circ} \mathrm{C}$. The duration of the experiment was $96 \mathrm{~min}$.

\subsection{Fast pyrolysis procedure}

The fast pyrolysis of flax shive was carried out in a screw-type laboratory set up [25] presented in Figure 2.

A sample of feedstock with a weight of $20 \mathrm{~g}$ was loaded into the loading device (1) with an electric lowspeed mixer which prevents the formation of bridging and ensures a uniform supply of flax shive particles to the screw feeder. The rate of rotation of the screw feeder is controlled by a device connected with the gear motor (4). The rotational rate of the screw feeder determines the residence time of the feedstock in the heated zone. The screw feeder is located inside the tubular pyrolysis reactor (2), which is heated using an induction furnace (3). The heating zone length is $10 \mathrm{~cm}$. After the heating zone, the reaction mixture passes the discharge hopper (5). Volatile products are collected in a flask (6) connected to a reflux condenser (7). Gaseous products are separated in a water trap (8), collected in a eudiometer (9).

The results of the preliminary experiments showed that the increase in feedstock residence time in a heating zone led to a significant increase in the resin yield. The decrease in the feedstock residence time, in contrast, led to the heat transfer limitation that results in a low degree of conversion. Based on the literature data [26] and the preliminary experiments, the fast pyrolysis process was carried out at a temperature range of $600^{\circ} \mathrm{C}$. The feedstock residence time in the heating zone of the reactor was $4.4 \mathrm{sec}$.

\section{Results And Discussion}

\subsection{Flax shive thermal analysis}


The data of thermogravimetric analysis of flax shive and the thermogram deconvolution obtained using NETZSCH Thermokinetics 3.1 tool are presented in Figure $3 a$ and $b$ respectively. The weight loose peak observed at a temperature range of $80-140^{\circ} \mathrm{C}$ (peak 1 in Figure $3 \mathrm{~b}$ ) indicates the dehydration of the feedstock and corresponds to the data obtained at the moisture content estimation (see Table 1). A wide peak in a temperature range of $210-450^{\circ} \mathrm{C}$ can be correlated with the thermal decomposition of the main biomass components - hemicelluloses, cellulose, and lignin [27].

Peak 2 (temperature range of $170-430^{\circ} \mathrm{C}$ ) corresponds to the decomposition of hemicelluloses of flax shive. Peak 3 (temperature range of $280-360^{\circ} \mathrm{C}$ ) indicates the decomposition of cellulose. Peak 4 (temperature range of $280-560^{\circ} \mathrm{C}$ ) correlates with the decomposition of lignin from the flax shive. The determined ranges of the flax shive component decomposition are well correlated with the literature data $[6,17,28,29]$.

To confirm the DTG modeling adequacy, the differential scanning calorimetric analysis was performed using NETZSCH DSC Q200 in a temperature range of $50-600^{\circ} \mathrm{C}$ with a heating rate of $10^{\circ} \mathrm{C} / \mathrm{min}$. The data obtained is presented in Fig. 4.

As it can be seen, endothermal effects with different intensities are observed at all temperatures studied. Peak 1 corresponds to the evaporation of water from the sample. As the humidity of the initial feedstock was quite high, the peak area seems to be high. Peak 2 can correspond to the summarized effects of the removal and decomposition of low-boiling compounds (i.e. extractives). Then, the endothermal effects of the decomposition of main flax shive components (hemicelluloses, cellulose, and lignin) can be observed. Peak 3 can correspond to the endothermal effects of the destruction of the thermal stable components of the lignin network.

During thermogravimetric analysis, a mass-spectrometry study of the volatile product of flax shive thermal decomposition was also performed in the mass range of 1-300 a.m.u. (see Fig. 5). The analysis was carried out using the mass-spectrometer device Aelos CSM 403 P (Netzch Group, Germany).

During thermogravimetric analysis, a mass-spectrometry study of the volatile product of flax shive thermal decomposition was also performed in the mass range of 1-300 a.m.u. (see Fig. 5). The analysis was carried out using the mass-spectrometer device Aelos CSM 403 P (Netzch Group, Germany). Thermal decomposition of flax shive samples results in the formation of a wide range of volatile products with a molecular weight from 40 to 90 a.m.u. which include both gaseous and liquid compounds. Moreover, the product formation is characterized by a wide temperature range.

\subsection{Pyrolysis product analysis}

To compare the process mode on the yield of pyrolysis product the estimation of product weights was carried out. The results obtained are presented in Fig. 6 . Slow pyrolysis provides a higher yield of gaseous and liquid products in comparison with the values obtained in the fast process. This can be explained by the increase in the feedstock conversion degree while increasing its residence time in the heating zone. Moreover, tar formation was not observed in the slow pyrolysis due to the behavior of the side reactions 
of tar decomposition. Interestingly to note, that the fast pyrolysis of flax shive is characterized by the relatively low yield of the liquid products in comparison with the literature data for biomass fast pyrolysis $[6,16]$. It can be connected with the high ash and char content which can catalyze the side cracking reactions as well as with the high humidity of the feedstock resulting in the behavior of syn-gas formation $[30,31]$. However, this characteristic can be concerned as positive for the use of the products in a gas-diesel cycle.

To estimate the influence of pyrolysis mode, a comparison of the composition of products was done. Table 2 presents the data on the composition and properties of gaseous products obtained by fast and slow pyrolysis. The analysis was performed by the gaseous chromatography method using the analytical complex based on the Crystallux 4000M chromatograph [32].

Table 2

Composition and properties of gaseous products of flax shive slow and fast pyrolysis (process temperature $600^{\circ} \mathrm{C}$ )

\begin{tabular}{|lll|}
\hline Value & Slow pyrolysis & Fast pyrolysis \\
\hline $\mathrm{V}_{\text {gas }}, \mathrm{mL} / \mathrm{g}$ of feedstock & 182 & 157 \\
\hline $\mathrm{CH}_{4}$, vol. \%. & 14.43 & 6.07 \\
\hline $\mathrm{C}_{2} \mathrm{H}_{4}$, vol. \%. & 0.53 & 1.17 \\
\hline $\mathrm{C}_{2} \mathrm{H}_{6}$, vol. \%. & 1.10 & 0.62 \\
\hline $\mathrm{C}_{3} \mathrm{H}_{8}$, vol. \%. & 0.20 & 0.14 \\
\hline $\mathrm{C}_{4} \mathrm{H}_{10}$, vol. \%. & 0.25 & 0.78 \\
\hline $\mathrm{H}_{2}$, vol. \%. & 6.93 & 5.49 \\
\hline $\mathrm{CO}$, vol. \%. & 18.76 & 18.10 \\
\hline $\mathrm{CO}_{2}$, vol. \%. & 12.74 & 3.50 \\
\hline $\mathrm{N}_{2}$, vol. \%. & 40.53 & 63.90 \\
\hline Tars, vol. \%. & 4.53 & 0.23 \\
\hline Lower calorific value, $\mathrm{kJ} / \mathrm{L}$ & 9.65 & 7.05 \\
\hline
\end{tabular}

According to the data obtained, the volume of gaseous products produced by slow pyrolysis per unit of the feedstock weight was higher than that obtained in fast pyrolysis. This can be explained by the higher residence time in the heating zone and, hence, by the higher degree of thermal decomposition [18]. The compositions of the gaseous products of slow and fast pyrolysis are close in terms of carbon monoxide 
and hydrogen concentration [33]. Slow pyrolysis results in the formation of a higher amount of methane (by 2.38 times), ethane (by 1.77 times), and propane (by 1.42 times). However, taking into account the low value of the total hydrocarbon concentration in pyrolysis gases, such difference does not strongly affect the calorific value. It should be noted that slow pyrolysis produces by 3.64 times higher yield of $\mathrm{CO}_{2}$ in comparison with a fast one. Meanwhile, the concentration of ethylene in gaseous products was found to be higher for the fast pyrolysis process (by 2.2 times); that can correspond to the decrease in the rate of secondary thermal decomposition processes.

The analysis of the liquid phase of the pyrolysis products obtained at $600^{\circ} \mathrm{C}$ was performed using GCMSQP2010S (SHIMADZU, Japan) according to the procedure described elsewhere [34]. The summarized results are presented in Fig. 7.

It is noteworthy that the liquid products contain a high amount of low-weight carbonylic and carboxylic compounds (i.e. acetic acid and acetates, acetone, etc.) which can be corresponded to the products of extractives and cellulose decomposition [35]. Furanes and pyranes obtained are the products of hemicelluloses and cellulose decomposition [35-40]. Phenols are formed during the destruction of lignin and hemicelluloses [31, 41, 42]. The composition of liquid products in both pyrolysis modes seems to be close to each other. However, fast pyrolysis results in the formation of a higher amount of carboxylic and carbonyl compounds as well as the furanes. It can be explained by the lower conversion of the feedstock and the decrease in the degree of lignin decomposition. Moreover, fast pyrolysis showed the formation of tars which can be the result of secondary processes such as aldol condensation.

To evaluate the physical properties of the liquid pyrolysis product the measurements of $\mathrm{pH}$, density, viscosity, and calorific value were carried out [43]. The pyrolysis liquid properties are presented in Table 3. It is well seen that liquid obtained by the fast pyrolysis is characterized by the higher $\mathrm{pH}$ value and density as well as the lower calorific value. This can be attributed to the increase in the concentration of acidic components in the product obtained.

Table 3

- Physical properties of liquid pyrolysis products (process temperature $600^{\circ} \mathrm{C}$ )

\begin{tabular}{|lll|}
\hline Parameter & Slow pyrolysis & Fast pyrolysis \\
\hline $\mathrm{pH}$ & 3.02 & 2.81 \\
\hline Density at $30^{\circ} \mathrm{C}, \mathrm{g} / \mathrm{cm}^{3}$ & 1.10 & 1.15 \\
\hline Viscosity at $40^{\circ} \mathrm{C}, \mathrm{cSt}\left(\mathrm{mm}^{2} / \mathrm{s}\right)$ & 27.9 & 28.2 \\
\hline Lower calorific value, $\mathrm{MJ} / \mathrm{kg}$ & 16.51 & 14.87 \\
\hline
\end{tabular}


Properties of the bio-char strongly depend on the process conditions such as temperature and heating time [19]. As carbon pyrolysis product is used as a sorption material, its porosity plays an important role. The solid residue obtained by the slow and fast pyrolysis at $600^{\circ} \mathrm{C}$ was analyzed by elemental analysis and low-temperature nitrogen physisorption. The analysis results are presented in Table 4.

Table 4

- Elemental composition and porosity of carbon residue obtained by slow and fast pyrolysis (process temperature $600{ }^{\circ} \mathrm{C}$ )

\begin{tabular}{|lll|}
\hline Parameter & Slow pyrolysis & Fast pyrolysis \\
\hline Elemental composition & & \\
\hline Concentration, wt. \% & 65.9 & 64.8 \\
H & 6.7 & 6.9 \\
O & 12.6 & 13.5 \\
N & 0.8 & 0.9 \\
Other elements & 14.0 & 13.9 \\
\hline Pore size distribution, \% & & \\
\hline$<6 \mathrm{~nm}$ & 29.28 & 20.48 \\
6-8 $\mathrm{nm}$ & 14.05 & 15.18 \\
$8-10 \mathrm{~nm}$ & 7.28 & 9.32 \\
$10-12 \mathrm{~nm}$ & 8.20 & 9.61 \\
$12-16 \mathrm{~nm}$ & 8.06 & 8.92 \\
$16-20 \mathrm{~nm}$ & 7.39 & 6.59 \\
$20-80 \mathrm{~nm}$ & 20.25 & 26.62 \\
$>80 \mathrm{~nm}$ & 5.48 & 3.28 \\
\hline Pore volume, $\mathrm{cm}^{3} / \mathrm{g}$ & 0.025 & 0.019 \\
\hline Specific surface area, $\mathrm{m}^{2} / \mathrm{g}$ & 1.7 & 1.1 \\
Langmuir model & 2.9 & 2.3 \\
BET model & & \\
\hline
\end{tabular}


Data of the elemental analysis show that for slow pyrolysis carbon content in the solid residue was higher, while the oxygen and hydrogen content were observed to be lower in comparison with the fast one. This can indicate the higher decomposition degree of the initial feedstock in the slow pyrolysis process. Moreover, as it was shown in [19], the surface of the solid residue obtained by fast pyrolysis is characterized by the higher concentration of hydroxyl groups.

The porous structure of the solid residues seems to be mesoporous for both process modes. However, the biochar obtained by the slow pyrolysis process is characterized by the higher specific surface area and narrow pore size distribution, while the carbon residue obtained by the fast pyrolysis shows wide pore size distribution. This is in the accordance with the literature data [20]. In slow pyrolysis, the cell structure of the initial feedstock does not practically change which leads to the retaining in the bio-char morphology. In fast pyrolysis, in contrast, the internal overpressure leads to the formation of internal cavities and the coalescence of small pores $[44,45]$.

\section{Conclusions}

This work was focused on the comparison of the yield, composition, and properties of gaseous, liquid, and solid products obtained by slow and fast pyrolysis of flax shive. Based on the results obtained, the following conclusions can be done:

(1) the slow pyrolysis process is characterized by the higher yield of gaseous and liquid products, and, hence, the lower yield of solid residue due to the higher depth of the feedstock conversion;

(2) the composition of gaseous products obtained by the slow and fast pyrolysis seems to be close regarding syn-gas. However, the formation of a larger amount of light hydrocarbons was observed in a slow pyrolysis mode. This resulted in the higher calorific value of gases in comparison with those obtained in the fast process;

(3) liquid product composition was found to be compatible for slow and fast pyrolysis. However, fast pyrolysis liquid is characterized by the higher $\mathrm{pH}$ value, density, and viscosity due to the higher concentration of acidic compounds;

(4) elemental composition of the biochar obtained by fast pyrolysis is characterized by the higher oxygen content, lower surface area, and wide pore size distribution due to the coalescence of small pores and internal cavities formation.

\section{Declarations}

\section{ACKNOWLEDGMENTS}

This work was financially supported by the Russian Science Foundation (grant 20-69-47084). 


\section{References}

1. Brown RC. (2019) Thermochemical Processing of Biomass: Conversion Into Fuels. Chemicals and Power. 2nd Edition. New York, Wiley.

2. Kazachenko AS, Miroshnikova AV, Tarabanko VE, Skripnikov AM, Malyar YN, Borovkova VS, Sychev VV, Taran OP (2021) Thermal conversion of flax shives in sub-and supercritical ethanol in the presence of ru/c catalyst. Catalysts 11(8):970. https://doi:10.3390/catal11080970

3. Dai L, Wang Y, Liu Y, He C, Ruan R, Yu Z, Jiang L, Zeng Z, Wu Q (2020) A review on selective production of value-added chemicals via catalytic pyrolysis of lignocellulosic biomass. Science of the Total Environment 749:142386. https://doi:10.1016/j.scitotenv.2020.142386

4. Liu C, Wang H, Karim AM, Sun J, Wang Y. (2014) Catalytic fast pyrolysis of lignocellulosic biomass. Chem. Soc. Rev. 43 (22):7594-7623. https://doi:10.1039/c3cs60414d

5. Mortensen PM, Grunwaldt JD, Jensen PA, Knudsen KG, Jensen AD (2011) A review of catalytic upgrading of bio-oil to engine fuels. Appl. Catal. A Gen. 407 (1-2): 1-19.

https://doi:10.1016/j.apcata.2011.08.046

6. Akhtar J, Saidina Amin N (2012) A review on operating parameters for optimum liquid oil yield in biomass pyrolysis. Renew. Sust. Energ. Rev. 16 (7): 5101-5109. https://doi:10.1016/j.rser.2012.05.033

7. Chen W, Chen Y, Yang H, Li K, Chen X, Chen H (2018) Investigation on biomass nitrogen-enriched pyrolysis: influence of temperature. Bioresour. Technol. 249: 247-253.

https://doi:10.1016/j.biortech.2017.10.022

8. Zhou S, Xue Y, Cai C, Ni Z, Zhou Z (2021) An understanding for improved biomass pyrolysis: Toward a systematic comparison of different acid pretreatments. Chem. Eng. J. 411: 128513.

https://doi:10.1016/j.cej.2021.128513

9. Carpenter D, Westover TL, Czernik S, Jablonski W. (2019) Biomass feedstocks for renewable fuel production: a review of the impacts of feedstock and pretreatment high-quality oil during the pyrolysis of lignin. Renew. En. 144: 147-152. https://doi:10.1039/C3GC41631C

10. Kumar R, Strezov V, Weldekidan H, He J, Singh S, Kan T, Dastjerdi B (2020) Lignocellulose biomass pyrolysis for bio-oil production: A review of biomass pre-treatment methods for production of drop-in fuels. Renew. Sust. En. Rev. 123: 109763. https://doi:10.1016/j.rser.2020.109763

11. French R, Czernik S (2010) Catalytic pyrolysis of biomass for biofuels production. Fuel Process. Technol. 91 (1): 25-32. https://doi:10.1016/j.fuproc.2009.08.011

12. Isahak WNRW, Hisham MWM., Yarmo MA, Yun Hin T-Y (2012) A review on bio-oil production from biomass by using pyrolysis method. Renew. Sust. En. Rev. 16 (8): 5910-5923. 
13. Mettler MS, Vlachos DG, Dauenhauer PJ (2012) Top ten fundamental challenges of biomass pyrolysis for biofuels. En. Environ. Sci. 5 (7): 7797-7809. https://doi:10.1039/C2EE21679E

14. Anca-Couce A (2016) Reaction mechanisms and multi-scale modelling of lignocellulosic biomass pyrolysis. Prog. Energy Combust. 53: 41-79. https://doi:10.1016/j.pecs.2015.10.002

15. Gonzalez JF, Roman S, Encinar JM, Martinez G (2009) Pyrolysis of various biomass residues and char utilization for the production of activated carbons. J. Anal. Appl. Pyrolysis. 85 (1-2): 134-141. https://doi:10.1016/j.jaap.2008.11.035

16. Mohan D, Pittman CU, Steele PH (2006) Pyrolysis of wood/biomass for bio-oil: a critical review. Energy Fuel. 20 (3): 848-889. https://doi:10.1021/ef0502397

17. De Wild PJ, Reith H, Heeres HJ (2011) Biomass pyrolysis for chemicals. Biofuels. 2 (2): 185-208. https://doi: 10.4155/bfs.10.88

18. Al Arni S (2018) Comparison of slow and fast pyrolysis for converting biomass into fuel. Renew. En. 124: 197-201. https://doi: 10.1016/j.renene.2017.04.060

19. Yuan T, He W, Yin G, Xu S (2020) Comparison of bio-chars formation derived from fast and slow pyrolysis of walnut shell. Fuel. 261: 116450. https://doi:10.1016/j.fuel.2019.116450

20. Mortari DA, Perondi D, Rossi GB, Bonato JL, Godinho M, Pereira FM (2021) The influence of watersoluble inorganic matter on combustion of grape pomace and its chars produced by slow and fast pyrolysis. Fuel. 284: 118880. https://doi:10.1016/j.fuel.2020.118880

21. CEN/TS 14774-1:2009 Solid biofuels. Determination of moisture content by oven dry method. Part 1. Total moisture. Reference method. Moscow, RusStandard.

22. CEN/TS 14775:2009 Solid biofuels. Determination of ash content. Moscow, RusStandard.

23. ISO 1928:2009 Solid mineral fuel. Determination of gross calorific value and calculation of net calorific value. Moscow, RusStandard.

24. Augustine O, Opeyemi A, Oyinlola M, Temitayo EO (2015) Compositional analysis of. lignocellulosic materials: Evaluation of an economically viable method suitable for woody and non-. woody biomass. AJER. 4: 14-19.

25. Lugovoy YV, Chalov KV, Tarabanko VE, Stepacheva AA, Kosivtsov YY (2021). Fast pyrolysis of flax shive in a screw-type reactor. Chemical Engineering and Technology 44 (11): 2056-2063. https://doi:10.1002/ceat.202100251 
26. Bridgwater A, Peacocke G (2000) Fast pyrolysis processes for biomass. Renew. Sust. En. Rev. 4: 173. https://doi:10.1016/S1364-0321(99)00007-6

27. Reed TB, Das A (1988) Handbook of Biomass Downdraft Gasifier Engine Systems. Washington, U.S. Department of Energy.

28. Wang S, Dai G, Yang H, Luo Z (2017) Lignocellulosic biomass pyrolysis mechanism: a state-of-the-art review. Progress Energy Combust. Sci. 62: 33-86. https://doi:10.1016/j.pecs.2017.05.004

29. Yang H, Yan R, Chen H, Lee DH, Zheng C (2007) Characteristics of hemicellulose, cellulose and lignin pyrolysis. Fuel. 86 (12): 1781-1788. https://doi:10.1016/j.fuel.2006.12.013

30. Zhu H, Yi B, Hu H, Fan Q, Wang H, Yao H (2021) The effects of char and potassium on the fast pyrolysis behaviors of biomass in an infrared-heating condition. Energy. 214: 119065. https://doi:10.1016/j.energy.2020.119065

31. MuW, Ben H, Ragauskas A, Deng Y (2013) Lignin pyrolysis components and upgrading -technology review. Bioenergy Res. 6 (4): 1183-1204. https://doi:10.1007/s12155-013-9314-7

32. Lugovoy YV, Chalov KV, Tkachenko OP, Sulman EM, Wärnå J, Murzin DY (2015) Effect of ironsubgroup metal salts on polymer cord pyrolysis. RSC Adv. 5: 56460-56469. https://doi:10.1039/C5RA09656A

33. Arni S (2004) An experimental investigation for gaseous products from sugarcane by fast pyrolysis. Energy Educ. Sci. Technol. 13 (2): 89-96.

34. Chalov K, Lugovoy Y, Kosivtsov Y, Stepacheva A, Sulman M, Molchanov V, Smirnov I, Panfilov V, Sulman E (2017) Petroleum-containing residue processing via co-catalyzed pyrolysis. Fuel. 198: 159-164. https://doi:10.1016/j.fuel.2016.08.055

35. Mettler MS, Mushrif SH, Paulsen AD, Javadekar AD, Vlachos DG, Dauenhauer PJ (2012) Revealing pyrolysis chemistry for biofuels production: conversion of cellulose to furans and small oxygenates. Energy Environ. Sci. 5 (1): 5414-5424. https://doi:10.1039/C1EE02743C

36. Mettler MS, Paulsen AD, Vlachos DG, Dauenhauer PJ (2012) Pyrolytic conversion of cellulose to fuels: levoglucosan deoxygenation via elimination and cyclization within molten biomass. Energy Environ. Sci. 5 (7): 7864-7868. https://doi:10.1039/C2EE21305B

37. Zheng M, Wang Z, Li X, Qiao X, Song W, Guo L (2016) Initial reaction mechanisms of cellulose pyrolysis revealed by ReaxFF molecular dynamics. Fuel. 177: 130-141. https://doi:10.1016/j.fuel.2016.03.008

38. Zhou X, Li W, Mabon R, Broadbelt LJ (2018) A mechanistic model of fast pyrolysis of hemicellulose. Energy Environ. Sci. 11 (5): 1240-1260. https://doi:10.1039/C7EE03208K 
39. Wang S, Ru B, Lin H, Sun W (2015) Pyrolysis behaviors of four O-acetyl-preserved hemicelluloses isolated from hardwoods and softwoods. Fuel. 150: 243-251. https://doi:10.1016/j.fuel.2015.02.045

40. Patwardhan PR, Brown RC, Shanks BH (2011) Product distribution from the fast pyrolysis of hemicellulose. ChemSusChem. 4 (5): 636-643. https://doi:10.1002/cssc.201000425

41. Vorwerk S, Somerville S, Somerville $\mathrm{Cn}$ (2004) The role of plant cell wall polysaccharide composition in disease resistance. Trends Plant Sci. 9 (4): 203-209. https://doi:10.1016/j.tplants.2004.02.005

42. Patwardhan PR, Brown RC, Shanks BH (2011) Understanding the fast pyrolysis of lignin.

ChemSusChem. 4 (11): 1629-1636. https://doi:10.1002/cssc.201100133

43. Xu Y, Hu X, Li W, Shi Y (2011) Preparation and Characterization of Bio-oil from Biomass, in Shaukat S (Ed.) Progress in Biomass and Bioenergy Production. Budapest, InTechOpen.

44. Della Rocca PA, Cerrella EG, Bonelli PR, Cukierman AL (1999) Pyrolysis of hardwoods residues: On kinetics and chars characterization. Biomass Bioenergy. 16:79-88. https://doi:10.1016/S09619534(98)00067-1

45. Kurosaki F, Ishimaru K, Hata T, Bronsveld P, Kobayashi E, Imamura Y (2003) Microstructure of wood charcoal prepared by flash heating. Carbon. 41: 3057-3062. https://doi:10.1016/S0008-6223(03)004342

\section{Figures}

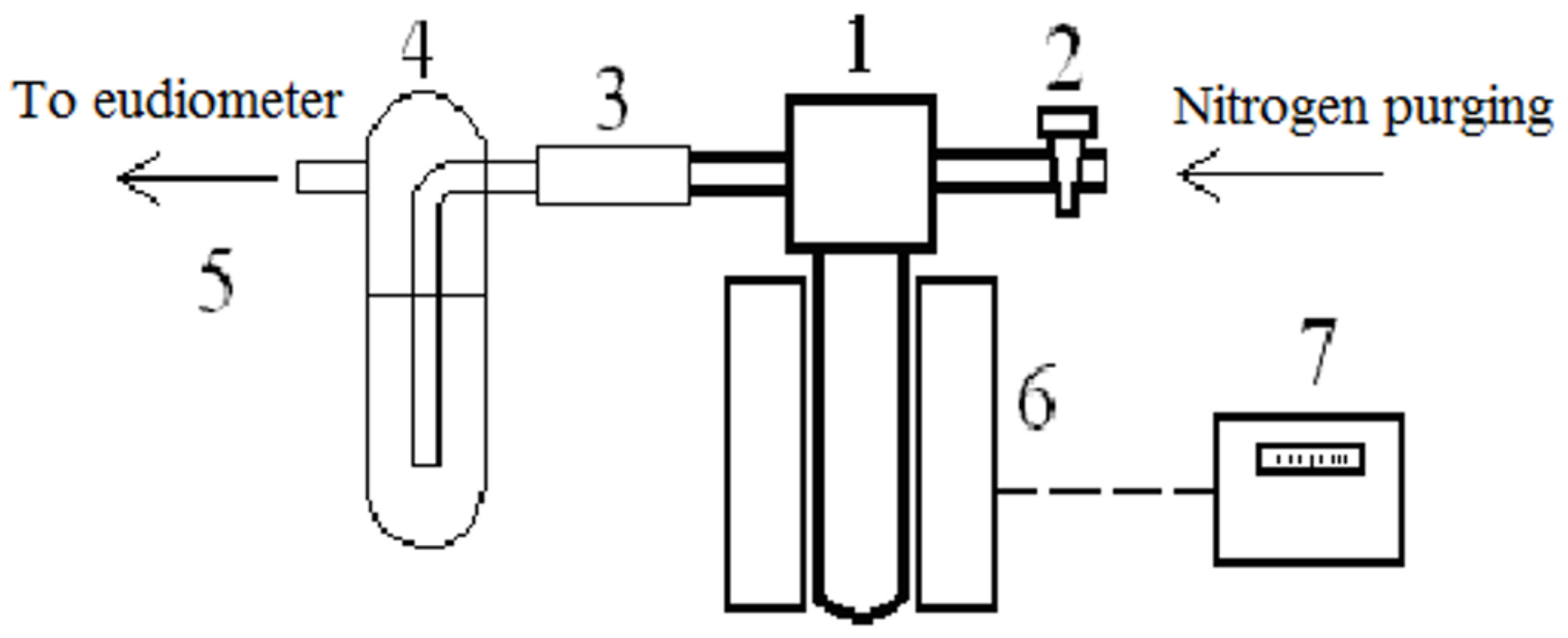

Figure 1

Scheme of the laboratory set up for slow pyrolysis 


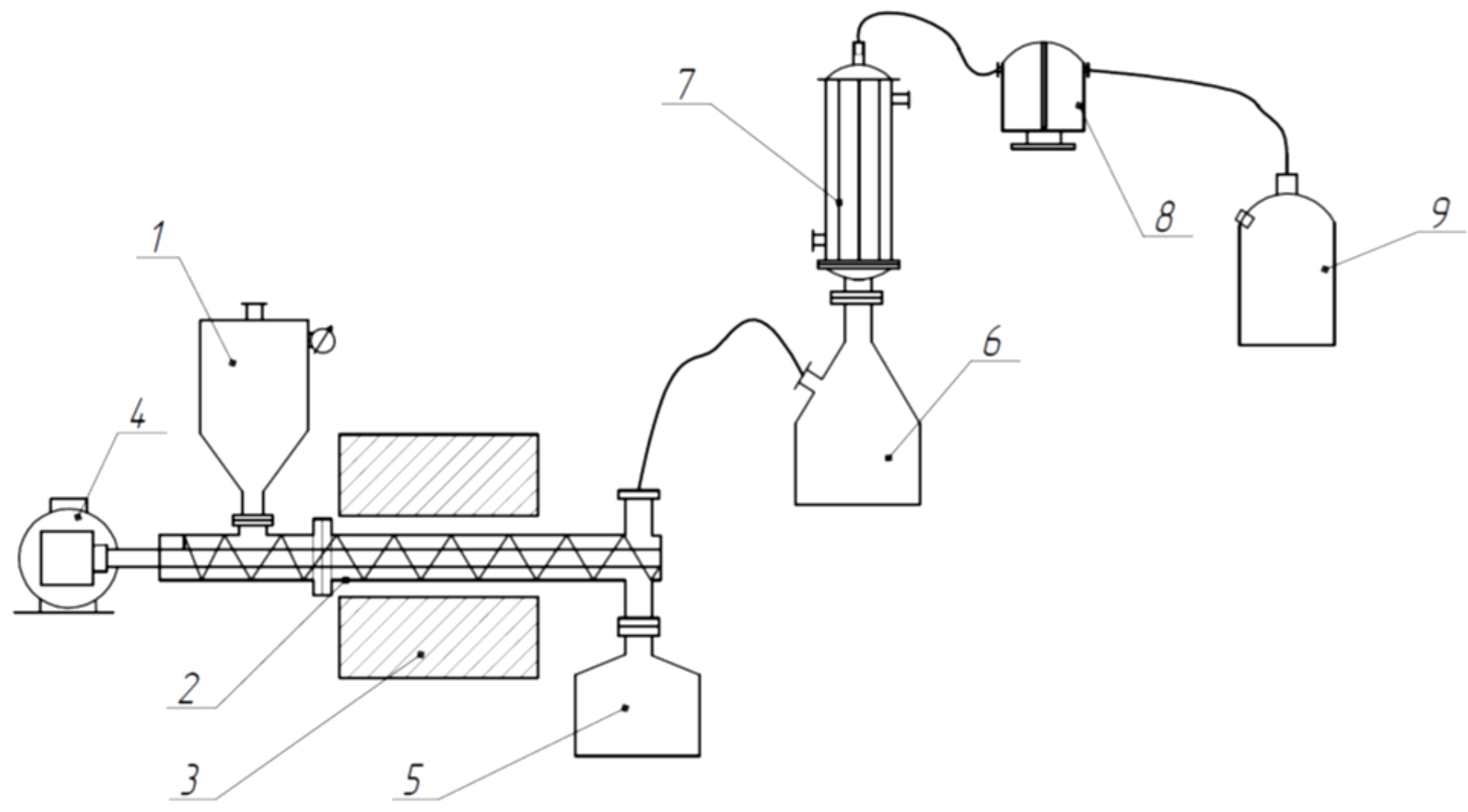

Figure 2

Scheme of the laboratory set up for fast pyrolysis
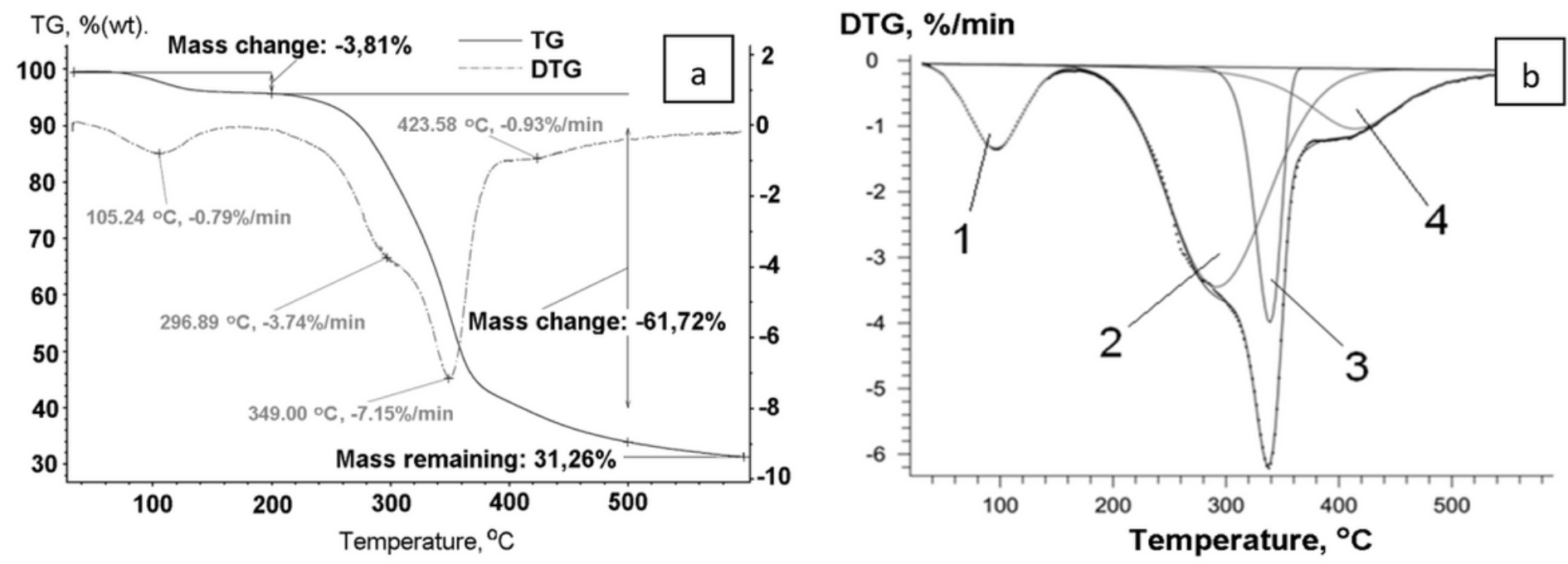

Figure 3

Flax shive thermogram in a temperature range of $30-600{ }^{\circ} \mathrm{C}$ (a) and DTG deconvolution (b) 


\section{$\mathrm{DSC}, \mathrm{mWt} / \mathrm{mg}$}

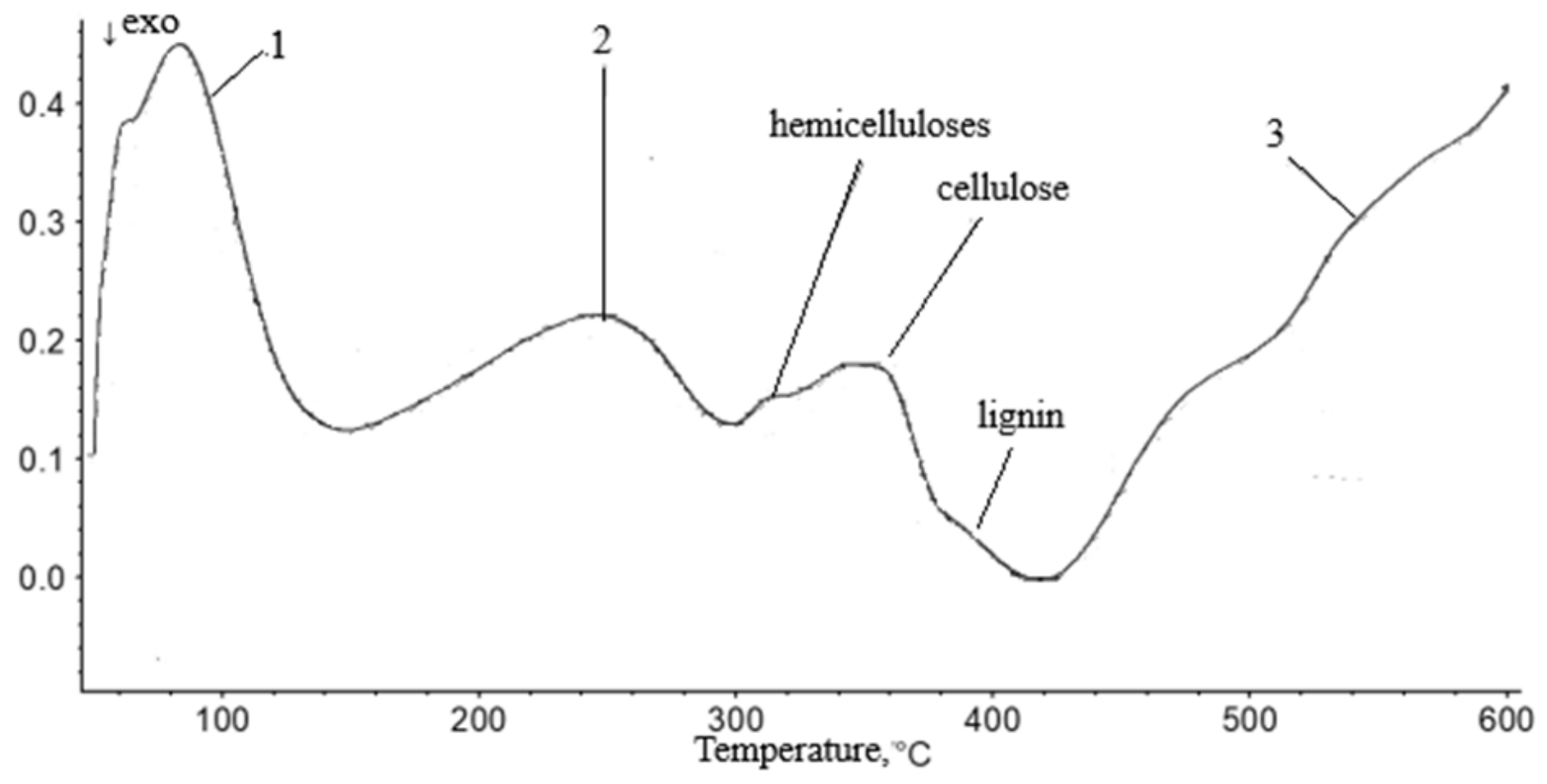

Figure 4

DCS curves of the flax shive 


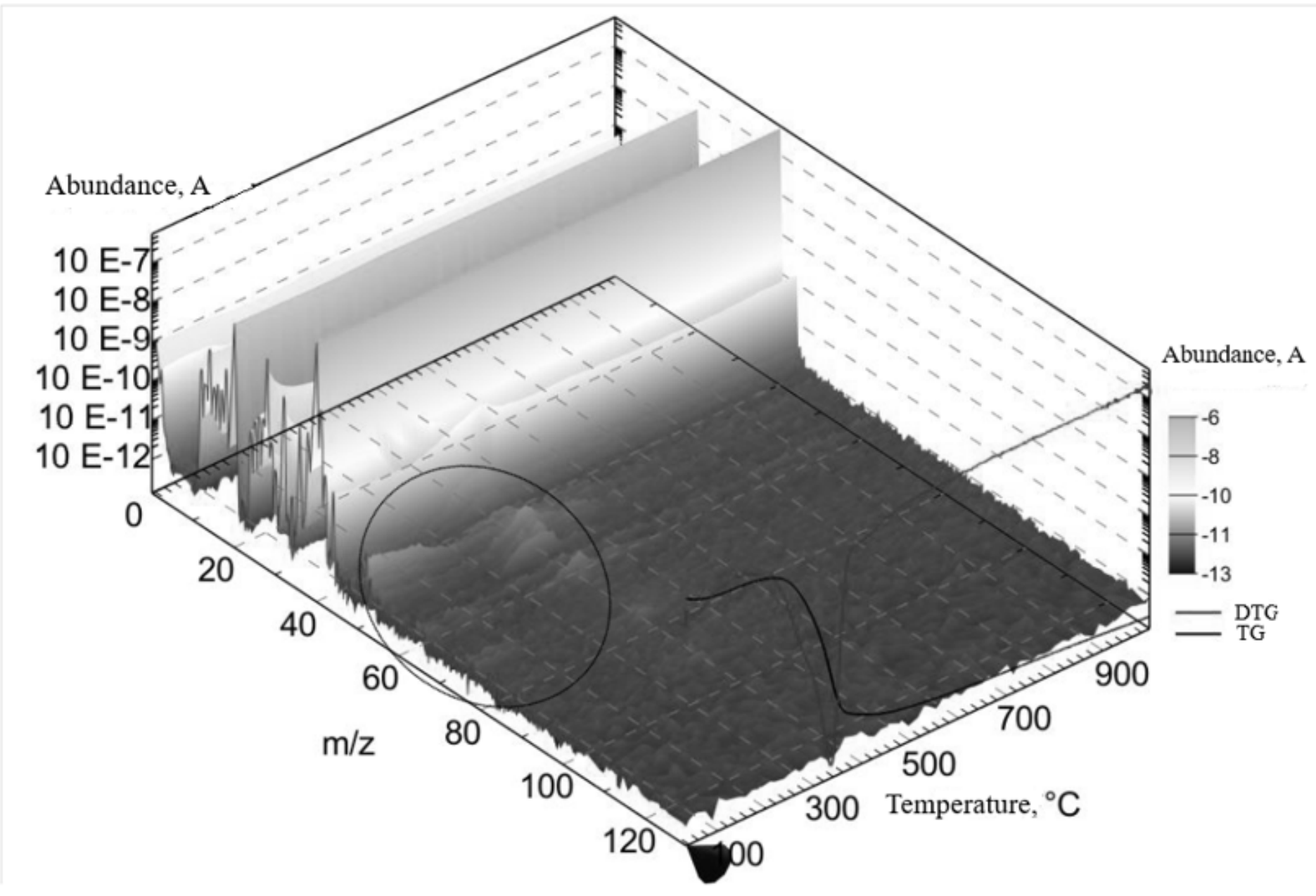

Figure 5

Mass spectrometric study of volatile products of flax shive thermal decomposition 


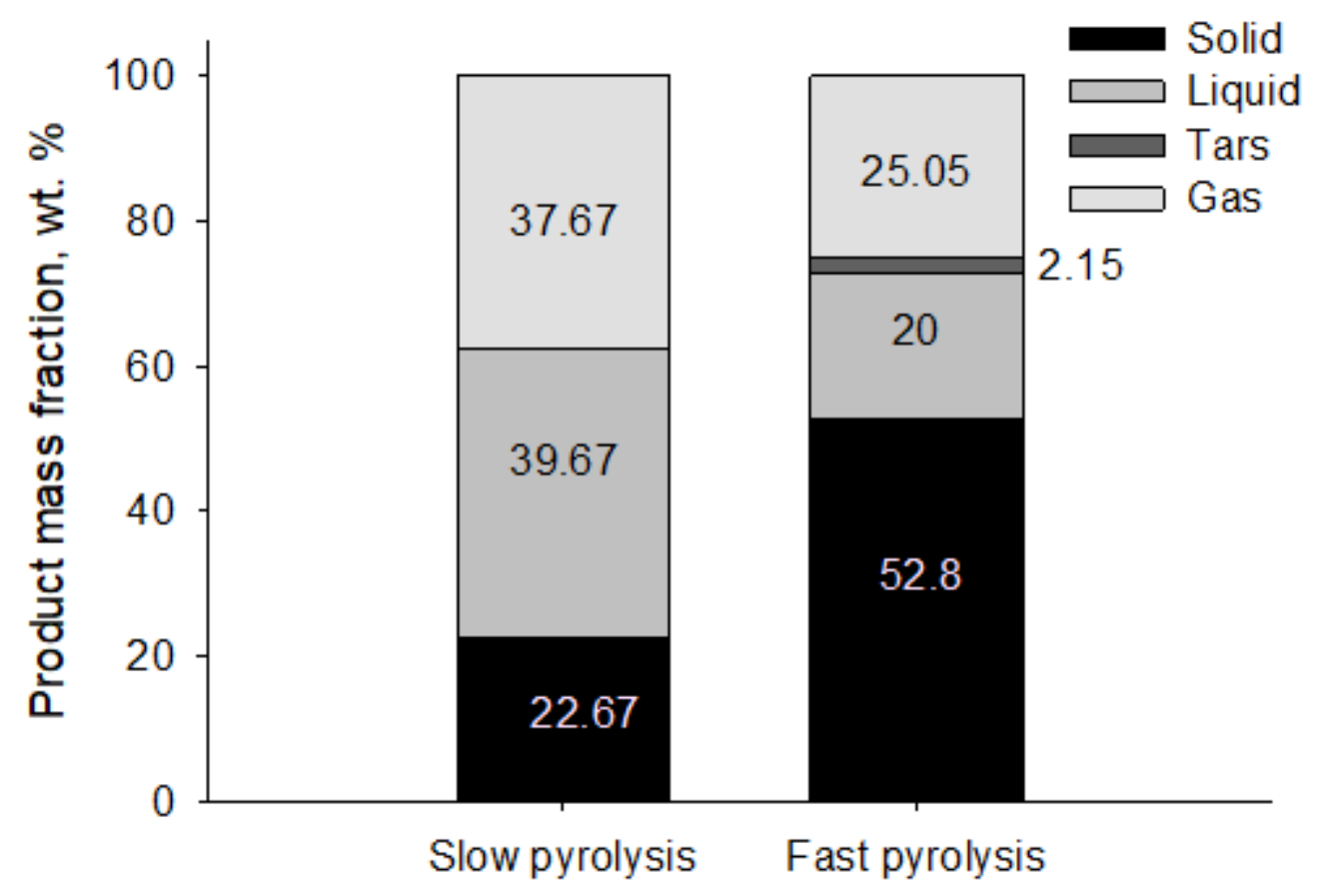

Figure 6

Product distribution for slow and fast pyrolysis of flax shive (process temperature $600^{\circ} \mathrm{C}$ ) 


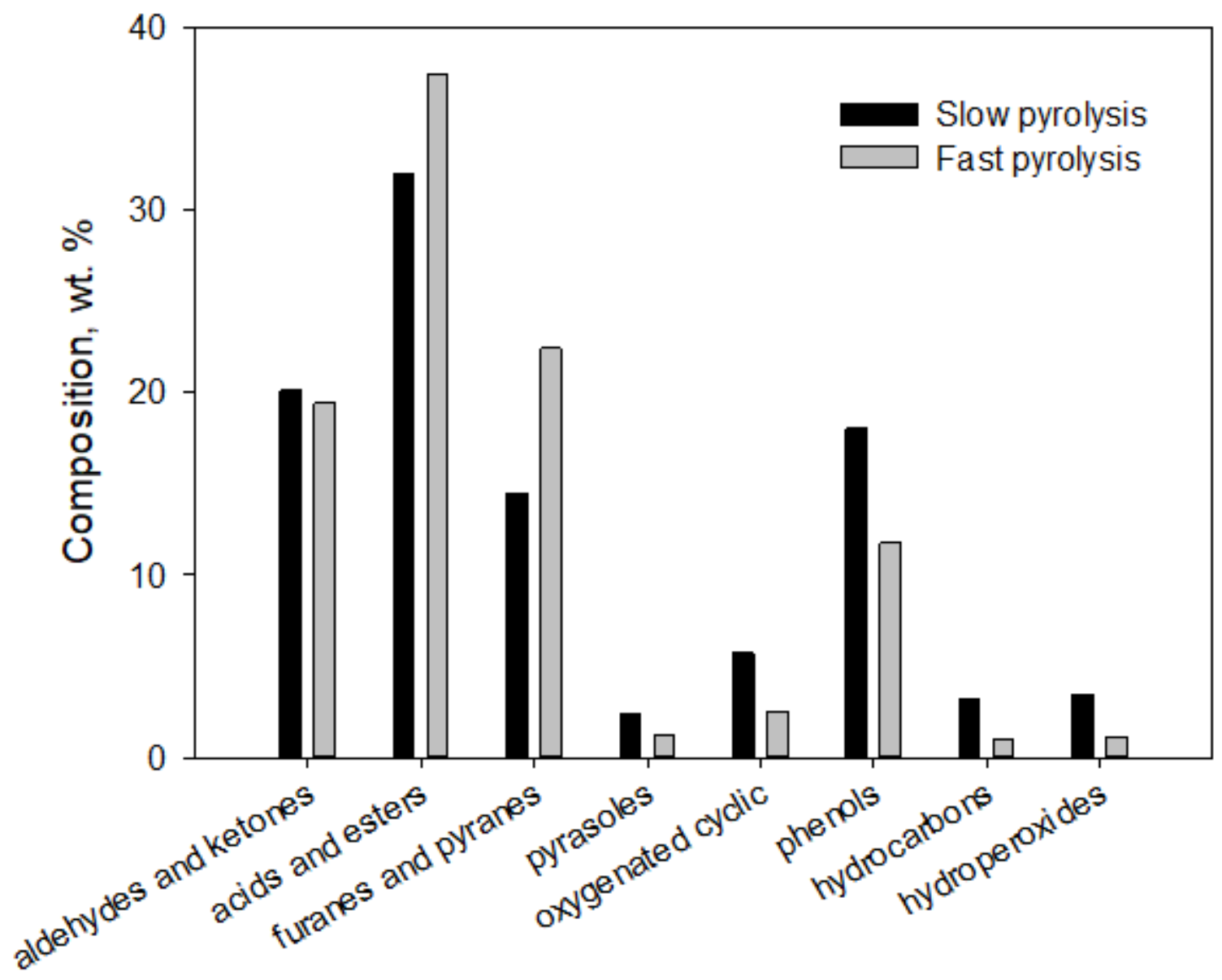

Figure 7

Liquid product composition for slow and fast pyrolysis (process temperature $600{ }^{\circ} \mathrm{C}$ ) 